\title{
Authenticity of Classical Arabic and its relation to Aristotelian Logic (In the opinions of some orientalists and Arab scholars)
}

\author{
Salahuddin Mohd. Shamsuddin ${ }^{1, *} \&$ Siti Sara Binti Hj. Ahmad ${ }^{1}$ \\ ${ }^{1}$ Faculty of Arabic Language, Sultan Sharif Ali Islamic University, Gadong BE 1310, Brunei Darussalam \\ *Correspondence: Faculty of Arabic Language, Sultan Sharif Ali Islamic University, Simpang 347, Jalan Pasar \\ Bahru, Gadong BE 1310, Brunei Darussalam. Tel: 678-364-851. E-mail: shamsuddinsalahuddin@gmail.com
}

Received: June 10, 2017

Accepted: July 18, 2017 Online Published: August 25, 2017

doi:10.5430/wje.v7n4p122

URL: https://doi.org/10.5430/wje.v7n4p122

\begin{abstract}
Classical Arabic was originated in the family of Semitic languages as a result of mixing among the languages of the people who lived in the Arabian Peninsula. Nobody knows the exact time of its emergence. We had some knowledge by some stone monuments and oral histories indicated that some distinct languages were in the south and north of the Arabian island. Some of their images remained for us that were sometimes seen in some Arabic dialects later in the aspects of their expression, derivation and synonymous words. The age of this classical Arabic is mentioned by al-Jāhị in his book: "The Animal”, which is between 150-200 years before Islam.

There is no doubt that Arabic Language has evolved through the ages and has become a standard language after it was audible, especially when it established its linguistic bases to protect its originality and Arab nature from the melody entered from the non-Arabs who accepted Islam, after the mixing among Arab Muslims and the other people. It is true that Arabs had used the Aristotelian logic in the development of their linguistic sciences, but their Arabic was not affected by the Aristotelian logic and their Arab culture did not lose its originality and nature.
\end{abstract}

Keywords: Arabic language and its nomadic nature; Compilation and codification; The fundamental differences between the nature of Aristotelian logic and grammatical rules in Arabic; Character of Linguistic Sciences in Classical Arabic

\section{Introduction: (Historical Background of Arabic Language)}

Arab culture had developed through various stages of its development. It has been passed by Arab societies and markets before the complement of its linguistic characteristics. Its people practiced its arts that flourished and grew up, and memorized its poetry and prose. When it rose up and reached every amount of its perfection, it stood on the threshold of the language of al-Qur'an in its linguistic miracle, bowing before the method of its miracle, which is shown in its linguistic characteristics. The linguists of Arab tongue recognized the greatness of its graphic style and rhetorical secrets, but it was not a wonder.

No doubt that each language has its suitable place. If we try to quote here what is written about it before, it will not be enough. Therefore, it is better to choose a page that was written by Mușțafă Șādiq al-Rafi'īin his book: "History of Arabic Literature and Classical Arabic", he says: "It is decided by the wise men that the language is rich because of its vocabularies. The wide condition of their disposing is a clear evidence for the civilization of its people and their capacity under the shadow of their society. There is nothing to mention for Arabs except that they had a literal civilization characterized by the nature; as they had noting in the science of metals and places of industries. There was not in their hands the tools of nations and social facilities except a few belongings do not reach in its entirety to be a brief explanation of the term (Arabs) in the dictionary of nations. The wisdom that made the old civic arts in the hands of Chinese and civic sciences in the minds of Greeks, it summarized that the civilization of languages is for the tongue of Arabs.

If we think about the meaning of civilization, including its benefit for us, we have seen it in every society in two forms: The first form is the image of the individual in his core. The second is the apparent image of the group. The urbanization will not be true only if it is based on the mental qualities found in per capita including the preparation for the virtues that are the material of change in the mental growth and creation of a new origination entails the 
emergence of history in total. There is no doubt that the apparent atmosphere of the group is the mirror of inner changes in the individuals. The society in its meaning is such as the combined effects of the minds and the history of psychological changes.

If we consider that in Arabs we have not seen it in them as the fact nor as the appearance, but only in the language, because it is not enough for Arabs to be on an innate morality protected by the borders of desert, and maintained by the walls of natural liberty, so that it can be said that there is a developing soul in Arabs for the literature; because this literature did not occur the mental changes in them that can appear in the image of their group, but in the last reign of their ignorant age when they entered in Islam, but if we consider their language we see the fact of urbanization represented, with all of its necessary conditions; it was the sea of life, which focused all the elements spewed out of / from this mental power in their own perfect language.

The wisdom gave their nature this linguistic system, and made them do the best for the process of its perfection, so that they do not face any obstacle to change their faces from the civil system. They went on that language beyond the social grades step by step, and at the end they became united in the unity of a nation in the world, then they changed completely, as a new young force faced by the old countries with a shock that demolished the history and then they wrote a new history. If there was not this language, Arabs could not be organized because their generations had spent before in the urbanization of their language, but they did not prove any talent in themselves, they did not consider the social system of the nature, which is a way to save the life, to complete the system of life, as it is concerned by the social civilization. The language lead them to the social ethics by the poetry, to the policy guided by the rhetorical speech and to the religious guided by the Qur'an.

The faces of urbanization that suit the natures of the civilian purposes are those Grammatical Signs that specify the meanings and purposes by the most convenient signal, that are the features of mental Highness specifically. (Al-Rafi ' $\mathrm{i}$, 1940)

This is the standard classical Arabic. In this book we selected the linguistic sciences at Arabs, as an attempt to study their advantages, such as the knowledge of grammar, morphology, semantics, dictionaries and Arab rhetoric. Let us look at these linguistic sciences in terms of the tradition and modernity, as the location of modern linguistic sciences of art for the languages of other peoples in the world.

\section{Advantages of Arabic Language}

All languages in the world have a particular importance, because the language is a tool of expression and imagination of human feelings and emotions. So the languages are such as a mirror for the life of nations and peoples. In this mirror we can see the pictures full flipped to their culture, civilizations, geographic regions, development, customs and traditions: Their happiness and sorrows, societies and economy, living natural sources and factors of death. The languages are like the human urbanization, such as the men that are divided into peoples and folks, into the colors and the homelands. They live in some certain geographical areas in the form of tribes of peoples, the tribes branch out to the families. The family is made up of the individuals and persons have the different natures, such as the features of their faces, their characteristics of their identity and colors.

The languages are also distributed and deployed in the geographical areas and also have families, like the family of Semitic languages, Aryan languages and languages of Indo-European family and so forth. The vocabularies and words are members of these families, including the words being known to all and familiar to them, such as: The word used for the father and mother, sister and brother, husband and wife, son and daughter, and so on, and the words known by only a few persons. Some of them are not known very well commonly. Therefore, the people need to know them by using the glossaries and dictionaries. We cannot recognize the advantages of the human as a person and his qualifications at the first glance or a single glance. Perhaps the pros autobiography and identity of his character can be discovered in multiple years and after a long period of living with him, as well as there are words carry a world of concepts and meanings inside themselves that are in the human conscience. If the expressive words were not found, the chests of people were the graves of the meanings and thoughts. The people differ in recognizing the meanings and concepts enshrined in the chests in a quantity and quality. Therefore, some critics said that every word has a meaning, then, there is a meaning of the meaning or shade of the meaning. The shades of meanings do not disappear from the personal sense of the word. Therefore, it should be noted that there is always a spirit behind every word (Ibid)

Arabic language has a wider and more comprehensive grammar so that it almost absorbed the whole language, but it does not mean that it does not need to be developed, because the words are renewed, these grammatical rules of 
Arabic appears to the presence of speech in the era of codification of the grammatical rules in Arabic. While there is no basis for the remembrance and feminization in many languages of peoples in the world.

The Qur'an is the primary source of Islamic religion, it is a source of the laws and provisions, the language of Qur'an is on the maximum score of the eloquence and the statement, every word of expressions in the verses of Qur'an is eloquent and fluent. Today there are many dialects of the vernacular languages in the Arab world, but only the classical Arabic is understood by everyone from Yemen to the Arab West. This is also one of the miracles of the Qur'an.

The second advantage of the classical Arabic is the presence of Hadith, as the prophet said: "I am the most eloquent among Arabs and Persians". He said, "I am awarded by the conciseness of speech". It is an exciting miracle of wonder that the tongue of Prophet that uttered the words of Revelation and verses of the Qur'an pronounced the words of Hadith. However, their tone and nature is completely different as the trail. All those who learn Classical Arabic accurately know the differences between the verses of the Qur'an and Hadith. This is the advantage of Classical Arabic from the religious point of view.

The third advantage is its literary importance, when the songs were featured, the poems were sung, the divans were written in the form of poetry and prose, and the stories were drafted in Arabic, many languages of the world went into / were in a deep sleep. Actually, the word (poetry) and (poet) is taken from the classical Arabic in many Asian languages, such as Urdu, Persian and Turkish, etc., and also the term of rhyme used in the poetry is taken from Arabic words. In fact, the vocabularies: such as the style, colors, eloquence, semantics, good style of the statement and what is related to the literary genres and the purposes of poetry as the whole can be referred to the Arabic language originally, because they originated under its custody. Hence, songs or arts of poetry appeared among the Arabs at first that were not known by the name of poetic poems at that time, but by the songs. (Ibid)

The fourth advantage is connected to the linguistic aspect, as the Arabic language includes the concision and redundancy, but the concision and redundancy here is used in the sense that anyone can explain his purpose with in two or one hundred words. Therefore it is a rich language because of its vocabularies, and it is the most powerful and wonderful language in the world in terms of its impact on the soul and its rhetorical statement in the field of speech.

It is one of the linguistic features in Arabic that the vocabularies also change their forms in the possessive and adjective cases, such as the vocabularies of intimacy, love and longing have different degrees of the statement to explain the one emotion. We also find more than a hundred words for the camel or the sword in Arabic, as well as the word "revenue" was used for going to the resources of water by the camel and the word "version" was used for returning back after being irrigated, although these two words are used today in Arabic for the "import" and "export".

The rules of Arabic grammar are also more comprehensive so that they might have to absorb all of the language, but that does not mean they do not need to be developed, because the speech is renewed, these grammatical rules in Arabic appear / appears to the presence of the speech, which had come about until the era of codification of Arabic grammar, so they covered the linguistic needs of that era, while there was no rule for the masculine and feminine in many languages of the people and nations of the world. Hence, the Arabic speakers distinguish between them with an arrow. In Arabic there are multiple weights for the feminization, plural forms, collective nouns and plural of the plural: (Collective combination), as well as, there are some certain formats for the preference and reduction, though a single word denotes several meanings, but it has a different meaning sometimes when it is in a plural form.

It is one of the features characterized in Arabic that every word is made up of three characters. If the word is a verb, it branches out to ten sections for more than three characters, including other derivatives. If someone knows a word that has three characters, the meanings of these derivatives can also be understood, by this way he can know the meanings of fifty words derived from the one material. This advantage is only for the Arabic language, and not for the other languages.

The standard Arabic was the language of sciences in the middle ages when it explained what was discovered by Muslim scientists in the field of nature, chemistry, mathematics, astronomy and the others... Indeed, Arabic language is a container of an extensive civilization that has a deep impact and an extended history. (Ṭāhā)

Arabic language has a very broad range. In the pre-Islamic era Arabs pride themselves on the other foreigners because of the eloquence of their words and tongues. They differentiated between Arabs and Non-Arabs because of the Arabic language, and considered the other Persian foreigners like the voiceless person who cannot express what is in his soul by his tongue, so the words to Arabs were not just sounds thrown by the tongue, but the means of decisive influence in the listeners, addressing and attracting them. Therefore, the maker of these Arab Lyrics was a poet who was the owner of the knowledge and awareness, and had an extraordinary magical knowledge in their 
opinion. So they respect the poetry, because it is decorated with life and they feared because of its charm and hidden powers. (Awaḍ, 1999)

According to a saying narrated: "Arabs in the pre Islamic era were hanging the finest poem on the walls of Ka"ba", (Zaki) so as to demonstrate boasting with their eloquent Arabian poetry, then the Qur'an was revealed by God Almighty in Arabic language, to be one of the miracles of the illiterate Prophet.

It is important to be mentioned that Arabic is the language of the people who lived in the countryside, but the Bedouin language is considered more eloquent and reliable. When this language came out of its nomadic habitat in the Arabian Peninsula after the dawn of Islam and mingled with the languages of other nations and peoples, changed their characters, as they were influenced by the Arabic character, such as Persian language began to be written with Arabic letters. In Persian about fifty per cent of its vocabularies are still originated from Arabic. (Ahmad, 1989) We can-briefly say that there is no one among the languages in South Asia and the (South East Asian region that could prevent itself from being influenced by the Arabic language as the minor or major impact, including the English language.

Arabic was the language of sciences in the middle ages when Muslim scientists developed their sciences in the nature, chemistry, mathematics, astronomy, etc. Indeed, Arabic has a deep-rooted history and extended culture. (Mandūr, 1988)

\section{Authenticity of Arabic Language in the Opinions of Orientalists}

There are some opinions of Orientalists in the dialect used by the Arab poets in their poetries.

- Theodor Nöldeke said: There were few differences between the dialects in the core parts of the Arabian Peninsula, such as Hijāz, Najd and region of Euphrates, this dialect (the fluent standard Arabic) developed by all of these dialects.

- Javidi said: It is not a certain tone to a particular tribe, but it is a mix of the dialects of the people in Najd and their neighbors.

- Fisher said: It was a certain tone, but he did not attribute it to any tribe.

- Nalino said: It was the language of those tribes were famous in the composing of poetry. The linguists and grammarians had collected their linguistic materials and examples from the people of those tribes. Those are tribes of Ma'd who were united by the kings of Kindah under the banner of a single provision before the middle of the fifth century AD. In his view it was generated from one of the civilized dialects in Najd in the time of the Kingdom of Kindah and became a literary language prevailed among the Arabs. (Ali)

- Brockelmann claimed that the classical Arabic was a technical language, standing above the dialects, though it was fueled by all. (Carl)

- Shawqī Dayf has mentioned in his book: "The Pre-Islamic Era" four old Arabic dialects, three of them were written with the Southern script, these three are al-Thamudī, al-Lihyānī and al-Șafawī dialects. The fourth one is Nabatean, which is written in bold Aramaic script. He described: How did the classical Arabic grow? How did it evolve and become a flourished literary language? How did it became united under the leadership of Quraysh? (Daif)

Quraysh had a great influence because of its religious spiritual and material economical central position. It was based on guarding the Kā'ba. It's convoys were roaming all over the Arabian Peninsula. All of the tribes were meeting in the seasons of religious festivals, commercial markets and literary functions in this central place. Therefore, Quraysh was as a landing place for the travelers and authorized to be focused by their eyes and hearts. So Quraysh was working to refine its dialect and belongings, choosing what was the suitable word for the tongue and light in hearing from the dialects of all these tribes. Thus, it was able by its fluent tone to prevail the other dialects as whole and to be the standard classical language chosen by the Qur'an. (Zalām, 1992)

It is the language of Arabs, which is the richest language by its vocabulary and the oldest language by its history. It is a remaining language by its impact. It has the largest range, the eternity merits and patience. It has the sweetest logic, the easiest style, the spectacular effects and a lot of language materials. It is the widest for all that is under the common feeling or impede the mind: to achieve the sciences, the enactment of laws, photographing the imagination, and the limitation of facilities on the certain conditions and the consistency of its parts. It is the language of illiterate people who did not have the wisdom of Greece and workmanship of China, they lived and died, but it stayed after them moving on generation after generation. It is suitable for every time and place, because it has its growing factors 
and matter of survival and prosperity, which is rarely poised to the other languages, because it has the different ways for the linguistic development and indication. It overcomes the steady drainage, the derivation, the diversity of metaphor, metonymy and multiple synonyms, to sculpture, the heart and the substitution and localization. Therefore, it was honored by the inspiration of the Qur'an and the Sunnah by its tongue. (Al-Iskandarī)

\section{Authenticity of Arabic Language and Its Structure}

The authenticity of Arab culture is reflected in the opinion of Muhammad 'Abid al-Jābirī. He says:

"We mean by "the Arab culture" the total intellectual heritage descended to us from the Arab-Islamic civilization in the middle ages, that culture that registers itself in its beginning and the starting point of its formation. This starting point or beginning is called the era of "Recording": The era of the general cultural heritage in Arab-Islamic civilizational experience. It is the period between the middle of the second and third century since the migration to form the frame of reference for Arab thought in all of its fields. We don't know anything about the Arab culture, but after the era of "Recording", and what was written in that era itself.

It must be understood that the "codification" was not only the registration and the restriction that existed before, but also it was the general cultural reconstruction, with all that was involved in the process of deleting, increasing, highlighting, hiding, coloring and interpretation... by the different Ideological or sociocultural factors. In this era, the language was codified, Arab-Islamic sciences were developed, and philosophy and "sciences of the formers" were translated into Arabic.

As al-Jābirī in his book: "The Heritage and Modernity" explained the authenticity of the relationship between Arabic language and its intellectual structure in Arab culture at several levels:

\section{A. Authenticity of Arabic as the language materials}

As it is known that the process of collecting the materials of Arabic language began in the era of "Recording" after the melody began to erupt in Arab society where non-Arabs became a majority. Whatever the real motive of this process was, the result is that the collection of materials of Arabic language, as it was done, helped to continue to deal with the Qur'an in a way that belonged directly to the understanding and interpreting.

Since the reason of melody was the mixing that took place in the cities, it was normal to ask for the "correct language" in the villages and among the tribes that remained isolated, and the nomad Arabs who maintained the "instinct", "style" and "right pronunciation".

Indeed, the narration of the language became an industry and professionalism at the beginning of the second century of emigration, when the men appeared to have mobilized their material and intellectual energies for this purpose. The most prominent of them was 'Abu 'Amr b. al-'Alā (d. 154 AH.), Hammād al-Rāwiyya (d. 155 AH) and al-Khalīl b. Ahmad (d. 170 AH.). It was in the forefront of the conditions of those who had the materials of Arabic language that he must have "rough skin" i.e. a pure Arab did not know the life of the city and the civilization did not "spoil" his Bedouin Arab culture. Just as the competition was strong to find the most estrange material in the wilderness and isolation. The competition was even more intense than the rare language, which led those Bedouin who had the use of materials that needed, by passing some time, to lie and untruth, undergo a phenomenon that had spread so much that those words became acceptable as long as they, the words, were concerned to the words of the Bedouin in the construction and meaning, those words that did not smell the smell of civilization. (Abduh, 1976)

The result is that the classical Arabic: The language of lexicons, poetry and literature had been and continued to convey to its people an increasingly distant world from their real world, which was a Bedouin world, living in their minds, imagination and consciousness, which was different to the increasingly civilized and complex world of civilization completely.

\section{B. Authenticity of Arabic as the grammatical templates}

Indeed, the "hearing" from Arabs was not always to "take" the language, but was also to "achieve" the theoretical assumptions in the language or Arabic grammar. Khalil's method of collecting the language material and developing a lexicon was a method adopted by all Arabic dictionaries with some minor modifications, was based on a right methodological principle that reveals an outstanding genius and mathematical mentality, but the practical results of its application in the field of language have entirely negative aspects. Khalil then began to collect the language material and its organization from the "intellectual possibility" rather than the linguistic motto, thus allowing the field to develop the language instead of collection. Rather, his method was primarily based on language development: The synthesis of Arabic alphabets with each other to formulate all possible words that have two, three, four and five 
letters, hence the formulation of Arabic language can be seen as a whole. Despite the tremendous efforts made by him and his linguistic colleagues to distinguish between these theoretical linguistic groups between the words used and the neglected, it was difficult and even impossible to draw a final line between what was said by the Arabs and what they did not say, especially in an atmosphere where a strange word was needed. In this situation it was natural to make the arbitration of "analogy" instead of hearing, which made the lexicographical language a language of possibility, not the language of reality: So the words were true, because they were possible and not because they were realistic, and they were possible as long as there was an origin. They were not realistic because the "branch" was mostly a theoretical prescription and not dictated by the extrapolation or social experimentation.

On the other hand, the adoption of derivation, especially the so-called "great derivation" has resulted in the consecration of the view that stems from the word to the meaning. If we note that the words from which the derivation is derived are the actions, we realize that how this view from the word to the meaning will also start from "the original verb" to the derivatives. These derivative nouns are not subject to "the hearing" in the process of their derivation, but there are some weights have been put in place that are in fact some logical templates for their derivation.

It may be useful to compare these Arabic grammatical logical templates with Aristotelian arguments that are related to Greek language. Taking into account the fact that the sentence - and thus the thinking - in the Greek language and the Aryan languages generally is derived from the noun, but in Arabic and the other Semitic languages generally, are on the contrary, it is derived from the act. (Ṭāhā, 1979)

\section{Authenticity of Arabic as methods of statement and its evidentiary nature}

If the grammatical templates in Arabic language are the statements or include the meaning of the sayings, the methods of the statement in Arabic or "rhetorical rules" in Arabic language in the term of Suyūtī, are used in the Arab discourse stand in place of the "inference" in the "logical discourse", and was understood by the Arab rhetoricians consciously.

In fact, the emergence of rhetoric in the Arab-Islamic culture was like other Arab sciences, motivated by an internal need of this culture itself and not because of external influence. The analysis of the rhetorical discourse was aimed at uncovering its internal logic in order to exploit the Qur'anic text in the field of Shari'a and doctrine. On one hand, it was necessary to deduce the legal provisions of the Qur'an from the organized knowledge of its methods of expression. On the other hand, it was necessary to face those who did not accept the miracle in the styles of its statement of this miracle. This is true that the establishment of rhetoric as one of the Arab-Islamic sciences was due to the former speakers, especially Mu'tazilites, who had to face those (the heretics and populists) who focused on denying the miracle of the Qur'an against Islam and all Arabs, hence it was necessary to reveal the "signs of miracle" in the Arabic speech, and explain "the secrets of rhetoric," in the statement in Arabic, this was addressed by the first rhetoricians who analyzed the rhetorical eloquent from its inside, i.e. without taking the frame of reference for them from Aristotle or any other, as a result they constructed the "second section" of the Arab logic (the logic of Arabic language) after the grammarians who had completed the construction of the "first section". The grammarians began to codify the discourse in Arabic and identify its words and logic.

The scholars of eloquence agree that all of the styles of Arabic statement are due to the analogy. "The analogy is going on a lot in the speech of Arabs even if someone said that the analogy is used in the most of their speeches, cannot be denied. So "it is an endless chapter". (al-Mubarrid, 1308). It is mentioned by the ancient peoples and the peoples of ignorance period from each generation that it was evidenced for the honor, preference and place of the rhetoric by all tongue." (al- 'Askarī, 1952). So it is "one of the noblest word of the Arab speech, and the wisdom is in them because of the analogy, whenever the speaker was successful in using beautiful analogies in his speech was talented in the knowledge of the poetry, and whenever he was the first in the explanation of the sense, was the best". (Ibn Wahb, 1967). In short, "the rhetoric is known as the analogy." (al-Bāqallanī) (1954). Analogy is that if you are master in its use you have the mastery in the arts of rhetorical magic." (al-Sakkākī).

The rhetorical miracle or the rhetorical inference in the Arab discourse is based on a kind of "epistemological repression", which stands as its structure on composing among different things by the means of sensual scenes in the words that hide the difference and show the coalition, leaving the chance to the listener or reader to extract the meaning himself after the suggested inspiration and direction beyond the discussion and objection. This "epistemological repression" is often raised to the point of "incriminating", when the author ejects his listener or reader with a series of analogies that show a sequence of images and sensory scenes that move from one idea to another without leaving him an opportunity to put the idea in question. 
It is needless to say that this "epistemological repression", which is based on rhetoric in Arabic belongs in its large part to the very nature of Arabic language: So in addition to its linguistic material associated with the sense links all the meaning to a sensory experience. It should be pointed out here that the rhetoric in Arabic, and thus this epistemological repression adopted by the rhetorical inference, is based on a breach of the balance between the words and meaning, so that the words in the phrase are less than the meaning to an extent that the listener has to complete the task by himself, on the contrary, sometimes there are several words used for the same meaning in one phrase, therefore, the listener finds the same hearing in front of a surplus of words offering himself as a compensation for the poverty of meaning.

\section{Authenticity of Arabic as the scientific research and its mental mechanisms}

Al-Jābirī says: Arab-Islamic sciences have emerged in overlapping and intermingling with the process of development of the grammar of the language, i.e. with the process of investing the Arabic words in order to formulate the relations among its elements in the rules. This was the first scientific work practiced by Arabs. It means that the sciences or linguistic sciences that appeared later, their techniques were taken from this pioneering science: Arabic grammar. Indeed, the grammatical measurement had been the basis of the jurisprudential measurement and theological reasoning. Al-Shāfi' ${ }^{'} \overline{1}$, the founder of Principles of jurisprudence did not invent the measurement as an invention, but he took it from the grammarians who came earlier to practice it consciously, i.e. as a specific method in producing and circulating the judgments. It was practiced by al-Khalīl $b$. Ahmad who died in $170 \mathrm{AH}$ and by his student Sibwayh (died in $180 \mathrm{AH}$ ). It is well-known that al-Shāfi 'ī lived after both of them. He did not compose his: "Message" in the principles of jurisprudence, but in $198 \mathrm{AH}$ and lived till year $204 \mathrm{AH}$. In addition, his "Message" was called "The Book", the same title was chosen by Sibwayh for his famous book in Arabic grammar. Although, it looks like al-Shafi' $1 \overline{1}$ wanted to do the same in the field of fiqh, which was done by Sibwayh in the field of grammar, therefore, it was necessary that he had to think of the same method and use the same epistemological device used by the grammarians. Perhaps it has a particular significance in this regard that the message of al-Shäfi' $1 \overline{1}$ in the origins of jurisprudence begins with a chapter entitled: How can be the statement? Rather, the message as the whole is almost a search in the way that must be followed to understand the religious texts, i.e. to invest in the jurisprudence. Is the principles of jurisprudence are something else different to this? Yes, the scholars have codified and developed the measurement, but we must not forget that the field in which it arose and formed as a way of producing knowledge is the field of grammar.

In the theology (science of speech), which was in its early stages, especially, a "linguistic science", i.e. "science of speech" in the religious texts. The reconciling between reasoning and narrated sciences cannot be carried out without the text, as the narration is the text itself? Here too the grammar will be practiced. The rhetorical researches have an impact in a general manner on the method of the speakers of the theology, especially in "the method of formers of them". The inference of the witness to the absent, which is called "the inference" in theology (science of speech), similarly as the measurement of the absent on the witness to the grammarians and Jurists. Perhaps, the approach of the speakers in the measurement is closer to the approach of grammarians in the measurement than to the approach of the jurists, particularly in terms of reference to the sense in reasoning. Ibn Jinni says: "You have to know that the reasoning of the grammarians is closer to the reasoning of the speakers than to the reasoning of the jurists" (Ibn, 1952-1956). If the inference of the grammarians to the words of Arabs is a natural thing, and if the jurists return to the language in order to understand the meaning of the words and their different meanings in the process of investing the religious texts, and it is also understandable, it is really an interesting thing that the theologians (speakers) inference to the language and take it as a reference authority in the definition of the metaphysical concepts.

If we recognize here the primacy of linguistic research in the establishment of the method of jurists and theologians (speakers) particularly, this does not mean that the effect was unilateral. No, the influence of jurists and speakers on the late grammarians is very clear. It is enough to note that how the philosophers of grammar, i.e. those who wrote in "the origins of grammar", reproduced the doctrine of jurisprudence, adopting its epistemological concepts weaving along the lines of its general structure? It is also interesting that such philosophers of the grammar went to engage many of the concepts of theology (science of speech) in their grammatical researches, such as the concept of "motion", "presentation", "reason", etc. Nevertheless, the linguistic character had dominated all these sciences, not only because the methodological research in the language was the founder of every subsequent methodology, but also because the subject of research, whether in jurisprudence or speech, was always the text.

\section{Difference between Classical Arabic and Ancient Greek Language}

In fact, now it is clear from an epistemological point of view that Arab-Islamic Sciences with their different names 
and the contrast of their objectives can be called as a single science, which aims to invest in the texts. Whether it is related to the religious sciences such as the interpretation, Hadith, jurisprudence, theology (science of speech) or the linguistic sciences such as grammar, morphology, rhetoric, the research always spins around the text.

It has become clear that the vision about the world offered by Arabic language to its people through its vocabulary as compiled in the era of codification largely reproduces the world of the nomadic Bedouin in the wilderness. It is far from the civilization and urbanization, because it is a world of the desert with its animals, tools and unhistorical sensual characters.

On the other hand, it is clear that Arabic language with its grammatical patterns and its explanatory rhetorical methods to some extent determines the way of thinking, the method of persuasion and conviction in the Arab intellectual linguistic space.

It also became clear that the curriculum in Arab-Islamic sciences and its connection to the linguistic research is one, which is the measurement: Measuring a part on another part or an absent on a witness.

Finally, it was also revealed that the system of knowledge established by Arabic language is only one of the three cognitive systems that established the Arab-Islamic culture: the Arab explanatory rhetorical system, Persian mystical hierarchical system and Greek system of proof.

On one hand, al-Jābirī has dealt with the differences among the scholars of the texts from Sunnis, the early Ashā'ira and all of the ancient Salafis, and the other trends in the Arab-Islamic thought: Theology, philosophy and mysticism on the other hand. He said that it mostly turns to the fact that the scholars of the texts put in their hands the system of knowledge provided by Arabic language alone, not from any other side, and made it for them a reference authority, which had its borders that cannot penetrate. While the other trends tended to adopt "some foreign systems of the knowledge" that were translated into Arabic, so it was such as "the creation of a language in a language prescribed among its people", as it is said by al-Sirāfî, i.e. the infusion of an intellectual structure into another intellectual structure, but they both cannot be combined in one system, which made the collision inevitable.

In light of what we have studied previously, the difference between the classical Arabic and the ancient Greek are as follows:

A. Greek language and Aryan languages, generally, start from the noun, but Arabic and the other Semitic languages, generally, start on the contrary, from the verb.

B. The arguments of addition, status and ownership do not belong - in the eyes of Muslim Arabs - to the human, but only by the way of metaphor, because the man is not the real owner, but the owner is God, and what is attributed to the human has not the truth, because the truth is that the real actor is God alone.

C. The root in Arabic grammar is an indication of an act without the time, whereas Greek mentality does not accept the occurrence of anything outside the time. The time and action both are inseparable. The "grammatical root" cannot be equivalent to the "logical essence" in any way. The root in the grammar is an act, but it is an act without the time, just an event.

D. The nominal sentence in Arabic is not a subject and a predicate, as it is in Aristotelian logic, but it is a noun comes in the beginning of the sentence, and then its information, to the Arab grammarians. It is not here to issue a rule carried by the subject, but it is only an information about the noun, which is mentioned in the beginning of the speech, which is originally an actor from whom the act has been performed or done, so the act comes later than the presence of its actor.

E. Arab grammarians were fully aware of this difference or the contradiction between Greek logic and Arabic grammar, and they viewed Aristotelian logic as the grammar of Greek language and Arabic grammar as the logic of Arabic language. "Arabic Grammar is a logic, but it is fabricated from Arabic, and Logic is the grammar, but it is understood by the language." Hence the use of Aristotelian logic in Arabic language is counted as "the creation of a language in the language prescribed among its people". Therefore, Aristotelian logic is in a space and the tongue of Arabs in another space.

F. Arab-Islamic sciences have developed in an overlap with the process of development of the grammatical rules of the language, i.e. with the process of investing the speech of Arabs in order to formulate relations between its elements in the rules. This means that the subsequent sciences or linguistics have derived their techniques from this pioneering science: Arabic grammar. 


\section{Conclusion}

At the end of this research, we summarize the differences between the quotes of Aristotle and Arab grammarians that are as follows:

1. The absence of the list of Arabic derivatives (arguments of the Arab grammarians) from the opposite of the attribution, situation and ownership of the property can be explained by the fact that the origin of the derivations is the act.

2. Similarly, Aristotle's statements that correspond to the root and name of the tool in the list of Arab derivatives, can be interpreted by the fact that the name of the tool indicates the tool of action, and the tool indicates the event, i.e. the act without the time, thus there is no meaning to carry it to the essence. The absence of Aristotle's statements that corresponds to the root in the list of grammatical derivatives in Arabic has a particular significance.

3. The derivation of the name of the time and place from the verb in the list of Arab grammarians indicates that they both are related to the act. The time is the time of the act (verb) and the place where it occurs, therefore, each of them (act, time and place) has a different significance, separately, without any relationship.

4. We must not be confused here because Bașarians say that the origin of the derivatives is the root, not the act, such as Kufis say. In addition to the fact that Kufis were the true interpreters of the nature of Arabic language, because the "grammatical root" cannot be equivalent to the "logical essence" in any way. The root in the grammar is an act, the action is not equivalent to the time, but just only an event.

Arab grammarians were fully aware of this difference - rather, the contradiction - between Greek logic and Arabic grammar, and they viewed Aristotle's logic as the grammar of Greek language and Arabic grammar as the logic of Arabic language. This is clearly reflected in the position of the grammarian 'Abu Sa'īd al-Sirāfì in the famous debate held between him and Abu-Bishr Matthew b. Yunus in Baghdad in the year $326 \mathrm{AH}$, at Council of Minister Faḍl b. Ja'far b. al-Furāt (Al-Tauhidī, 1978). The logic in the eyes of 'Abu Sa'īd al-Sirāfì "was developed by a man from Greek for their language according to their terms that they were recognizing with its characteristics, then it was not, but only for Greek people, therefore, he addressed Matthew b. Yunus, saying: "So you do not call us to the logic, but to learn Greek language" because the logic (Aristotle's logic) is the grammar of Greek language, as Arabic grammar is the logic of Arabic. Hence, there was the use of Aristotelian logic: its terms, concepts and requirements in Arabic language. In other words, its application in Arabic was as "the creation of a language in the prescribed language among its people". Al-Sirāfī objected to Matthew b. Yunus who wanted to distinguish between the grammar and logic on the basis that the first examines the words and the second examines the meanings, because this is an artificial distinction that has no basis.

Although in the later stages Aristotelian logic leapt widely into Arab Islamic sciences, especially, in terms of grammar, jurisprudence and theology, many of those who worked in these sciences felt as though they were actually "creating a language in the prescribed language among its people". They did not hesitate to declare that this overlap between the two languages or two logics is the reason for the multiplicity of doctrines and conflicts in Arab-Islamic culture. Al-Suyūṭi attributed to al-Shāfíī as saying: "The people were not ignorant and they did not differ, but they left the tongue of Arabs and tended to the tongue of Aristotle." (Suyūṭi, 1970)

However, no one can deny that the differences among the scientists of speech in Arab-Islamic culture were - at least in some of its part - due to the fact that the "speakers" used different languages at that time, even though they all spoke in Arabic. Some of them spoke the logic taken from Arabic while others spoke the logic of another language translated into Arabic.

Hence, we can say that there is a logic for Arabic language, which is known by the Arabic grammar, and has its own originality. There is another logic translated into Arabic from the Aristotelian logic of Greece, which has its originality as well, and there are some substantial differences between them that are worthy to research and study.

\section{References}

Al-Rafi'i. Mușțafā Șādiq. (1940). History of Arab Literatures. Beirut/Lebanon: House of the Arab Book. 1, pp. 213-218

Abduh Muhammad. (1976). Novel and citation of language. Cairo: The World of Books.

Aḥmad Rushdy Țu'aimā. (1989). Teaching Arabic to non-native speakers. Rabat: Islamic Organization for 
Education, Science and Culture (ISESCO). p. 31-32.

Al-'Askari. 'Abu Hilāl al-Hasan b. 'Abdullah. (1952). Book of the two industries. Cairo: Investigation: 'Ali Muḥammad al-Bagawi and Muḥammad Abu Fadl Ibrahim. Press of Issa al-Babi al-Halabi \& Partners. P. 231

'Ali. Jawād. (No date). The Islamic culture and contemporary life. "Dialects of the Arabs in pre Islamic Era". Cairo: Library of the renaissance.

Al-Iskandarī. 'Aḥmad and al-'Anānī. Muștafa. (No date). The mediator in Arabic literature and its history. Egypt: Dār al-Ma'ārif. p. 17

Al-Mubarrid. 'Abu 'Abbas Muhammad b. Yazid. (1308 H). The Perfect in the language and literature. Cairo: Charitable Press. 3, p. 818

Al-Tauhidī. 'Ali b. Muhammad 'Abu Ḥayyān. (1978). Al-Imtā' Wa Al-Mu'ānasa. Damascus: Selection and Presentation of Texts: Ibrahim al-Kilāni. Ministry of Culture and National Guidance.

Awaḍ. Țāhir 'Abdul Lațif. (1999). Arabic Literature. Cairo: Faculty of Islamic Studies (for Boys) University of Al-Azhar. pp. 116-122

Bāqllāni. 'Abu Bakr Muḥammad b. Țayib. (1954). Miracle of Qur'an. Cairo: Investigated by: Aḥmad Șafar. Dakhāyir al- 'Arab. Dār al-Ma'arif. P.12

Carl Brockelmann. (1977). History of Arabic Literature. Egypt: Dār al-Ma‘ārif. Part 1, p. 42

Ḍaif. Shawqī. (No date) The Pre-Islamic Era. Egypt: Dār al-Ma‘ārif. P. 131

Ibn Jinnī, Abu al-Fath \& Uthmān. (1952-1956). Characteristics in the philosophy of Arabic. Cairo: Investigated by: Muḥammad 'Ali Najjār. I. Second and third edition. Egyptian Book House. Part 1, p. 48

Ibn Wahab, Abu al-Husain Ishāa b. Ibrahīm. (1967). Proof in the object of the statement. Baghdad: Investigation: Ahmad Matlūb and Khadija al-Hudaini. Baghdad University. P. 130

Mandūr. Muhammad. (1988). Literature and its arts. Cairo: Nahdat Misr, for printing, publishing and distribution. P. 52

Mandūr. Muhammad. (1988). Literature and Criticism. Cairo: Nahdat Misr for printing, publishing and distribution. P. 19

..................... (No date). Cairo: Nahdat Misr for printing, publishing and distribution. p. 52

Sakkāki. 'Abu Ya 'qūb. (No date). Key of the sciences. P. 161

Suyūṭī. Jalāl al-Dīn 'Abu al-Faḍl 'Abdurrahmān b. 'Abu Bakr. (1970). Maintenance of logic and speech in the art of logic and speech. Cairo: House of Renaissance. Part 1, p. 47

Ṭāhā 'Ahmad Ibrāhīm. (No date). History of literary criticism among Arabs. Beirut: National Library. p. 15

Ṭāhā. 'Abdurraḥmān. (1979). Language et philosophie. Rabat: publications de la faculte des letters. P. 46

Zaki. 'Aḥmad Kamāl. (No date). Studies in Literary Criticism. Beirut: Dār Al-Andulus. p. 31

Zalām. Sa d. (1992). The artistic phenomena in the pre-Islamic poetry. Cairo: Dār al-Manār. p. 125 